\title{
The Implementation of Scientific Approach in Learning Science Through Problem Solving
}

\author{
Heffi Alberida ${ }^{1 *}$ \\ ${ }^{1}$ Biology Education, Math and Natural Science Faculty Universitas Negeri Padang, Padang, Indonesia \\ *Corresponding author. Email: alberidamatua@gmail.com
}

\begin{abstract}
Learning is a scientific process, therefore learning should be carried out in accordance with scientific methods, in the curriculum of 2013 known as a scientific approach. In learning, a scientific approach consists of five activities, namely: observing, asking questions, gathering information, associating and communicating. The results of a study of junior high school science teachers in Padang who attended The Curriculum of 2013Implementation training on June 23-27, 2014, showed that most of the natural science teachers were not able to apply the questioning activities in learning. The questioning activity is very important to develop students' critical thinking skills, as well as a benchmark for the activities of gathering information, associating and communicating. Learning science goal is to practice problem solving skills. Problem solving skills are important to have by students because they are related to the ability to solve daily problems by applied science concepts. The steps of problem solving are similar to the scientific method. The stages of problem solving consist of planning; obtaining data; data organizing; analyzing data; generalizing data. The process at the planning stage is to identify problems, formulate problems, and formulate hypotheses. The planning stage equals the inquiry stage in the scientific approach. Implementation of problem solving is supported by student books, Student Worksheets, and learning media, therefore the teacher becomes easier to apply including activities to formulate problems and submit hypotheses (ask questions).
\end{abstract}

Keywords: scientific approach, problem solving.

\section{INTRODUCTION}

Learning is all activities directed at students so they learn. Lufri (2007:9) stated, "learning is a matter of learning, which means it refers to all efforts to make a person learn, how to produce a learning event in a person.Learning must be interesting and fun. As explained in the Standard of Process for Elementary and Secondary Education Units, the learning process is conducted interactively, inspiratively, fun, challenging, providing conditions for activities, initiatives, creativity and independence according to students' talents, interests and physical and psychological development (Permendikbud. No 65 of 2013).

Learning is a scientific process. Therefore, the curriculum of 2013 mandates the essence of a scientific approach in learning process. The scientific approach emphasizes inductive reasoning rather than deductive reasoning (KementerianPendidikandanKebudayaan, 2013). Deductive reasoning observes general phenomena to get specific conclusions. In contrast, inductive reasoning observes specific phenomena or situations to get an overall conclusion.
Inductive reasoning puts specific evidence into a broader relationship. The scientific method generally places specific phenomena and studies to get conclusions.

Scientific methods are techniques for investigating phenomena or symptoms, for gaining new knowledge, or correcting and integrating prior knowledge. The scientific method must be based on observable, empirical, and measurable evidence with logical reasoning. Therefore, the scientific method contains a series of data collection activities through observation and experimentation, then formulating and testing hypotheses.

Science learning for basic education (elementary and junior high) aims to make children able to use science concepts to solve problems in daily life, both for students who will explore the science subject or not. Wieman C. (2007) stated that science learning aims to build the generation of scientific literacy, able to encounter global challenges, make decisions, understand various global issuesscientifically. Science literacy is knowledge and understanding of scientific concepts and processes which needed to make personal decisions, participation in public and cultural activities, and economic productivity (Rustaman et al., 2011). Science literacy in PISA 2003 is defined as the capacity to use scientific knowledge, 
identify questions and make conclusions based on facts in order to understand the universe and the changes that occur due to human activities. Therefore, the approach in learning science must be able to form students who are literate in science.

Learning in the curriculum of 2013 consists of five main learning experiences, namely: observing; asking questions; gathering information; associate; communicating (Appendix

iv. Permendikbud 81A 2013). These five learning experiences are appropriate with scientific approaches that prioritize

inductive reasoning. Learning activities and developed competencies in each learning experiences are shown in Table 1.

\section{MATERIALS AND METHODS}

Learning based on scientific approaches is more effective than traditional learning. The results of the study prove that only a few students are familiar with the explanation of concepts given clearly in traditional learning. This is illustrated by Wieman C., (2007) as follows.

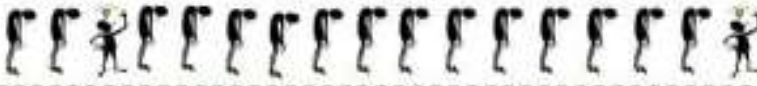

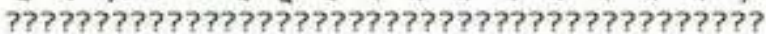

Fig 1. The student's reaction to the teacher's brilliant explanation (Wieman C., 2007)

Wieman C.'s next research is to compare traditional learning with learningbased on scientific approach with results as in Table 2.

Table 1. Learning experiences, learning activities, and developed competencies in each learning experience

\begin{tabular}{|c|c|c|}
\hline Learning Experiences & Learning Activities & Developed Competencies \\
\hline Observing & $\begin{array}{l}\text { Reading, hearing, seeing } \\
\text { (without } \\
\text { or with a device) }\end{array}$ & $\begin{array}{l}\text { Practicing sincerity, } \\
\text { accuracy, } \\
\text { seeking information }\end{array}$ \\
\hline Asking questions & $\begin{array}{l}\text { Asking questions about } \\
\text { information that is not } \\
\text { understood } \\
\text { or that you want to know }\end{array}$ & $\begin{array}{l}\text { Developing creativity, } \\
\text { curiosity, } \\
\text { the ability to make questions } \\
\text { to } \\
\text { form the critical mind that } \\
\text { needed to life smartly and } \\
\text { lifelong learning }\end{array}$ \\
\hline $\begin{array}{l}\text { Collecting } \\
\text { information/experiments }\end{array}$ & $\begin{array}{l}\text { Doing experiments, reading } \\
\text { books } \\
\text { other than textbooks, observing } \\
\text { objects / events / activities, } \\
\text { interviewing resource persons }\end{array}$ & $\begin{array}{l}\text { Develop creativity, curiosity, } \\
\text { ability to form questions, } \\
\text { critical thinking }\end{array}$ \\
\hline $\begin{array}{l}\text { Associating/processing } \\
\text { information }\end{array}$ & $\begin{array}{l}\text { Conducting experiments, } \\
\text { reading } \\
\text { books besides textbooks, } \\
\text { observing and interviewing } \\
\text { resource persons }\end{array}$ & $\begin{array}{l}\text { Develop a conscientious, } \\
\text { honest } \\
\text { attitude, respect the opinions } \\
\text { of } \\
\text { others, communicate, gather } \\
\text { information in various ways, } \\
\text { lifelong learning }\end{array}$ \\
\hline Communicating & $\begin{array}{l}\text { Deliver the results of } \\
\text { observations, discussions and } \\
\text { conclusions verbally, and in } \\
\text { writing }\end{array}$ & $\begin{array}{l}\text { Develop an honest attitude, } \\
\text { thorough, think } \\
\text { systematically, } \\
\text { the ability to express } \\
\text { opinions } \\
\text { briefly and clearly, the ability } \\
\text { to } \\
\text { speak good and right }\end{array}$ \\
\hline
\end{tabular}

(Appendix IV. Permedikbud 81A 2013) 
Table 2. Comparison of learning outcomes between traditional learning and learning based on scientific approaches

\begin{tabular}{|l|l|}
\hline Traditional Instruction & $\begin{array}{l}\text { Research-Based } \\
\text { Instruction }\end{array}$ \\
\hline Retention of informatic & Retention of informatic \\
\hline $\begin{array}{l}\text { From lecture: } 10 \% \text { after } \\
15\end{array}$ & $\begin{array}{l}\text { From lecture: more } \\
\text { than } 90 \%\end{array}$ \\
\hline Minutes & After 2 days \\
\hline Gain in conceptual & Gain in conceptual \\
\hline & $\begin{array}{l}\text { understanding: 50- } \\
70 \%\end{array}$ \\
understanding 25\% & $\begin{array}{l}\text { A small } \\
\text { improvement }\end{array}$ \\
\hline Beliefs about physics \\
and & \\
\hline problem solving & \\
\hline significant drop & \\
\hline
\end{tabular}

Table 2 shows that, in traditional learning, information obtained by students after 15 minutes of learning is $10 \%$. Whereas in learning with a scientific approach, information retention reaches more than $90 \%$ after 2 days. When viewed from the understanding of concepts, the understanding of concepts in traditional learning as much as $25 \%$ while in learning based on scientific approach, understanding of concepts reaches $50-70 \%$. The results of years of research conducted by Wieman C. bring out to the idea of using a scientific approach in classroom learning.

The learning process with a scientific approach must follow the rules of a scientific approach. The characteristics of a scientific approach are the prominence of the dimensions of observation, reasoning, discovery, validation, and explanation of a truth (KementerianPendidikandanKebudayaan, 2013). Thus, the learning process must be carried out with the guidance of scientific values, principles, or criteria. Furthermore the Ministry of Education and Culture, 2013 stated that the scientific learning process if it meets the following criteria

1. Learning material based on facts or logical phenomena; not just a fantasy, legend, or fairy tale.

2. Teacher explanations, student responses, and teacherstudent educational interactions are free from prejudice, subjective, or illogical reasoning.

3. Encourage students to think critically, analytically, and correctly in identifying, understanding, solving problems, and applying learning material

4. Inspire students to think hypothetically, understand differences, similarities, and relationships with one another.

5. Encourage students to be able to understand, apply, and develop rational and objective thinking in responding to the substance of learning.

6. Based on concepts, theories, and empirical facts that can be accounted for.

The learning objectives are formulated simply and clearly, but the presentation system must be interesting.
The learning process in the curriculum of 2013 for junior

and senior high school or equivalent is carried out using a scientific approach. The learning process includes three domains, namely attitudes, knowledge, and skills. The end of the result is an increase and balance between soft skills and hard skills. The curriculum of 2013 emphasizes the modern pedagogic dimension in learning, which uses a scientific approach.

The scientific approach in learning has broad meaning including the activities of observing, asking, trying, processing, presenting, concluding, and creating. In certain subjects, materials, or situations, a scientific approach cannot always be applied procedurally, however the learning process must still apply scientific characteristics. In accordance with Appendix IVPermendikbud 81A 2013, the scientific approach is summarized into five activities, namely: observing, asking questions, gathering information, associating and communicating.

\section{RESULT AND DISCUSSION}

\subsection{Teachers Understandingand Abilityto Apply Scientific Approaches}

The data of the teachers' understanding and ability to apply a scientific approach are taken after the teacher participates in "The Implementation of Curriculum of 2013 in Padang". The teacher's understanding data on the scientific approach was obtained through a questionnaire, while the data on the teacher's ability to apply the scientific approach was obtained through observation using an observation sheet. Questionnaires were given today of "The Implementation of Curriculum of 2013 in Padang" activity. The teachers' understanding and ability to apply a scientific approach is shown in Figure 2.

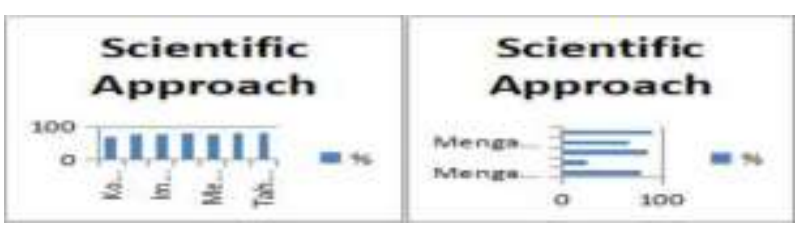

Figure 2. The graph of understanding and ability of teachers to apply a scientific approach

that are in accordance with the scientific approach. The highest understanding is at the stage of the scientific approach (more than 80\%). When implementing a scientific approach in the classroom, teachers generally have no problems when carrying out activities of observing, gathering information, and communicating. However, almost all teachers have difficulties when implementing questioning activities. Teachers have not been able to facilitate students to be able to ask critical questions, especially to formulate hypothetical questions that will be proven in the learning process. 
Questioning is a learning activity, which students ask questions about information that is not understood or questions to get information about observations (ranging from factual questions to hypothetical questions) (Appendix

Permendikbud 81A 2013). According to this description, the students who ask questions, the teacher facilitates so students are able and accustomed to asking questions. In the first stage, the teacher may "force" students to ask questions. Ask each student to write questions according to their observations on the paper, give a few moments so they can think. After that, each of them read the questions they had made. The teacher should write on the board each student question, then mark the main questions that will be answered through further activities. If a question does not appear, the teacher must motivate until the student can formulate the question correctly. The teacher must not directly give questions/problems.

Asking questions is one of the science process skills (SPS). Questioning activities include asking what, why, how; ask questions to ask for an explanation; and asking hypothetical questions. SPS is a skill and therefore needs to be trained to students, as well as asking questions

The problem in the field is that teachers are not yet familiar with questioning activities. To help science teachers be able to apply a scientific approach in the classroom, we need a model of learning tools that can be used as guidelines. Alberida (2017) has developed a problem solving based worksheet. Alberida (2018) has also developed a problem solving model (PSM) for learning science at JHS. PSM is proven effective in increasing SPS (Alberida, 2019), and critical thinking (Latifa and Alberida, 2019).

B. Retationship of Problem Solving with Scientific

Approach

Some approaches that can be used in science learning are learning objectives, concept approach, environmental approach, inquiry approach, process skills approach, interactive approach, discovery approach, problemsolving approach and technological and community science approach (Rustaman N., 2005:92). Problemsolving approach is an approach that directs or trains students to be able to solve problems in the field of study they learn. The problem solving approach starts from the problem that must be solved through observation, practicum or literature study (Rustaman N., 2005:98).

Problem solving can be seen as the process of applying existing knowledge and understanding to something new. Kolesnik (1976) in Lufri (2003) stated the characteristics of problem solving include a conscious effort, deliberately looking for answers or conclusions, or solutions needed by individuals to achieve goals.

The best way for students to study science is to give them challenging problems and arouse their thoughts, habits of thought, and actions related to problem solving. Science involves ways of thinking and acting as a body of knowledge. The emphasis of sciencelearning is on thinking, problem solving and thinking habits that encourage exploration, discovery, curiosity, willingness to ask questions, open to ideas, and learn from mistakes. Problem solving-based science learning is the discovery of science concepts through a series of problem solving process activities. Problem solving is a skill that must be trained. To practice problem solving can be done through inquiry methods, case studies, games, role playing, research and discussion (Lufri, 2007: 30). All methods start from the problem, the difference is in the steps to solve the problem. According to Gagne (1970: 215) stages of problem solving are: 1) the presentation of the problem, 2) defining the problem, 3) formulating the hypothesis, and 4) testing the hypothesis. While the stages of problem solving according to Lufri (2007: 31) are 1) understanding the problem, 2) formulating the problem, 3) proposing alternative problem solving, 4) writing the mostappropriate solution and outlining the rationale so that the problem can be solved.

Problem solving can be either complex or simple. So that problems can be solved, students must apply three knowledge namely: rules, declarative knowledge and cognitive strategies (Gagne, 1980). In order to apply the rules in solving a problem, students must be able to recognize and identify the problem. Other than that students must also have the ability to remember declarative knowledge in order to solve problems. Declarative knowledge helps students to limit problems and look for possible solutions (set goals and alternative problem solving).

Problem solving contains two concepts, namely problems and problem solving. Problems are situations where solutions are not clear that confront individuals or groups to find solutions. Problem solving is the effort of individuals or groups to find answers based on prior understanding (Krulik\& Rudnick, 1996). So the problem solving activity begins with the problem (confrontation) and ends when an answer that is appropriate to the condition of the problem has been obtained.

Children who have the ability to solve problems will be able to solve the problems they face in everyday life by applying existing knowledge. If children have low literacy, so the ability of problem solving is also low. Therefore, the teacher must familiarize the child with problems and how to solve it. Through science learning, this ability can be trained. Teachers must prepare themselves to carry out learning, look for problems in accordance with the theme, for that teachers need adequate learning tools.

Natural Sciences as a process includes the ability to apply scientific methods to conduct investigations known as science process skills (Rustaman, 2011:1.9). Furthermore, Rustaman (2011: 1.37) said that one of the science process skills is problem solving knowledge and skills. Problem solving skills are important to have by students because they are related to life skills. Nowadays science learning in Indonesia lacks training in problem solving skills for students. The learning process at school needs to familiarize learning with the problem solving approach, so students have problem solving skills. 
Learning activities according to process standards (Permendiknas No. 65 of 2013) prioritize scientific activities (scientific approaches), for that learning should be based on discovery / inquiry. Meanwhile project based learning is suggested to encourage students to produce contextual work. Stenberg (1985) in Estes, Mintz and Gunter (2011: 126-127) stated the basis for carrying out discovery / inquiry-based learning is problem solving. According to Carin and Sund (1964: 35-41), problem solving, critical thinking and creative thinking including higher order thinking skills. Furthermore, Carin and Sund went on to state the purpose of learning science is to help students change perceptions, images, concepts for the development of problem solving skills.

There are many versions of problem solving according to the expert who developed it. In general, the problem solving stage is the same as the scientific method. The

\section{CONCLUSION}

From the discussion above, it can be concluded the following points

1. Learning is a scientific process

2. The scientific process in learning consists of five main activities, namely: observing, asking, gathering information, associating and communicating.

3. Learning with problem solving can facilitate teachers in implementing questioning activities.

\section{REFERENCES}

[1] Alberida, H., \& Barlian, E. (2018, April). Problem Solving Model for Science Learning. In IOP Conference Series: Materials Science and Engineering (Vol. 335, No.1, p. 012084). IOP Publishing.

[2] Alberida, H., \& Barlian, E. (2019, October). Enhancing student's science process skills through problem solving model: an effectiveness study. In Journal of Physics: Conference Series (Vol. 1317, No. 1, p. 012181). IOP Publishing.

[3] Carin, A. 1997. Teaching Science through Discovery, 8th ed. Ohio: Merril an imprint of Prentice Hall.

[4] Carin, A.andSund B. 1964. Teaching Science through Discovery. Ohio: Charles E Merril Books, Inc.

[5] Estes, T., Mintz S., and Gunter M. 2011. Instructions A Models Approach. Boston: Pearson Education, Inc.

[6] Gagne, R. M. 1980. Essential Learning for Instructions. Hindale: The Dryden Press. stages of problem solving that the author uses are the stages of problem solving in accordance with the opinion of Carin (1997), namely planning; obtaining data; data organizing; analizing data; generalizing data. The process at the planning stage is identifying problems, formulating problems, and formulating hypotheses. The planning stage is the same as the questioning stage in the scientific approach. The implementation of problem solving is supported by student books, studentsworksheets, and learning media, therefore the teacher becomes easier to apply including activities to formulate problems and propose hypotheses (ask questions).

[7] KementrianPendidikandanKebudayaan, 2013.ImplementasiKurikulum 2013

(AnalisisMateri Ajar,

KonsepPendkatanSaintifik). Jakarta: DepartemenPendidikandanKebudayaan

[8] Latifa, N. A., \& Alberida, H. (2019). The Influence of Problem Solving Model Toward Students' Critical Thinking Skills. Bioeducation Journal, 3(2), 113-120.

[9] Lufri.2003. Pembelajaran Perkembangan Hewan Berbasis Problem Solving yang Diintervensi dengan Peta Konsep dan Pengaruhnya Terhadap Berpikir Kritisdan Hasil Belajar Mahasiswa Biologi FMIPA Universitas Negeri Padang. Disertasi (tidakditerbitkan). UniversitasNegeri Malang.

[10] Lufri. 2007. StrategiPembelajaranBiologi, Teori, PraktekdanPenelitian. Padang: UniversitasNegeri Padang.

[11] OECD (2010), PISA 2009 Results: Learning to Learn - Students Engagement, Strategies, and Practices (Volume III) http://dx.doi.org/10.1787/9789264083943-en

[12] OECD (2010), PISA 2009 Results: What Students Know and Can Do - Students Performance in Reading, Mathematics and Science (Volume I) http://dx.doi.org/10.1787/9789264091450-en

[13] Permendikbud No. 65 tahun 2013 tentangStandar Proses PendidikanDasardanMenengah

[14] PermendikbudNo.81Atahun2013 tentangImplementasiKurikulum (lampiran iv) tentangPedomanUmumPembelajaran

[15] Rezba R.J., Sraque C., Fiel R., TT. Learning and Assessing Science Process Skills. Iowa. Kendall/Hunt Publishing Company 